\title{
Correction to: Incidence and factors associated with out-of-hospital peri-intubation cardiac arrest: a secondary analysis of the CURASMUR trial
}

\author{
Cédric Gil-Jardiné ${ }^{1}$ Patricia Jabre ${ }^{2,3} \cdot$ Frederic Adnet $^{4} \cdot$ Thomas Nicol $^{3} \cdot$ Patrick Ecollan $^{3} \cdot$ Bertrand Guihard $^{5}$. \\ Cyril Ferdynus $^{6} \cdot$ Valery Bocquet $^{7} \cdot$ Xavier Combes $^{1}$ (I)
}

Published online: 12 February 2022

(c) The Author(s), under exclusive licence to Società Italiana di Medicina Interna (SIMI) 2022

\section{Correction to: Internal and Emergency Medicine https://doi.org/10.1007/s11739-021-02903-9}

In the original publication of the article, the given name and family name of the author were swapped. The correct author name is given in this erratum.

The original article was corrected.

Publisher's Note Springer Nature remains neutral with regard to jurisdictional claims in published maps and institutional affiliations.

The original article can be found online at https://doi.org/10.1007/ s11739-021-02903-9.

\section{Xavier Combes}

Xavier.combes@chu-bordeaux.fr

1 Department of Emergency, CHU de Bordeaux, Place Amélie Raba Léon, 33076 Bordeaux cedex, France

2 AP-HP, Service d'Aide Médicale d'Urgence (SAMU) de Paris and Paris Sudden Death Expertise Center, Université Paris Descartes, Paris, France

3 Department of Anesthesia and Critical Care-SAMU, Assistance Publique-Hôpitaux de Paris, Hôpital Necker-Enfants Malades, Université Paris Descartes, 149 rue de Sèvres, 75015 Paris, France
4 Urgences-SAMU 93, Unite Recherche-Enseignement-Qualite, Hopital Avicenne, Bobigny, France

5 Department of Emergency, CHU de la Réunion, Université de La Réunion, Réunion, France

6 INSERM CIC 1410 Clinical and Epidemiology/CHU Réunion/Université de la Réunion, Saint-Pierre, Reunion, France

7 Departement d'Informatique Clinique, Centre Hospitalier Universitaire de La Réunion Site Félix Guyon, Saint-Denis, France 